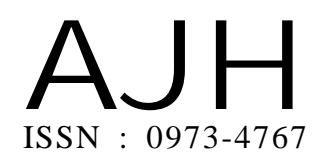

Article history :

Received : 20.02.2019

Revised : 01.05.2019

Accepted : 14.05.2019
Members of the Research Forum

Associated Authors:

${ }^{1}$ Department of Horticulture,

Agricultural College and Research

Institute, Tamil Nadu Agricultural

University, Madurai (T.N.) India
Author for correspondence :

V. Krishnamoorthy

Horticulture Research Station (TNAU), Dindugal (T.N.) India

Email : krishorttnau@gmail.com
THEASIAN JOURNAL OF HORTICULTURE

Volume 14 | Issue 1 | June, 2019 | 1-8

Visit us -www.researchjournal.co.in

\title{
Diallel graphical analysis of growth, yield and quality traits in pumpkin (Cucurbita moschata Duch. ex. Poir)
}

\section{Krishnamoorthy and P. Marxmathi ${ }^{1}$}

ABSTRACT : The present study on diallel graphical analysis was conducted at Department of Horticulture, Agricultural College and Research Institute, Tamil Nadu Agricultural University, Madurai during 2016 according to hayman on growth, yield and quality traits of pumpkin. Six advanced pumpkin genotypes viz., $\mathrm{P}_{1}$ : Acc.No. MDU CM23-Thirumangalam local, Madurai district, $\mathrm{P}_{2}$ : Acc.No. MDU CM28-Oddanchatram local, Dinddugul district, $\mathrm{P}_{3}$ : Acc.No. MDU CM29-Harur local, Dharmapuri district, $\mathrm{P}_{4}$ : Acc.No. MDU CM12-Department of Horticulture, AC and RI Madurai, $\mathrm{P}_{5}$ : Acc.No. MDU CM1-Attur local, Salem district, $\mathrm{P}_{6}$ : Acc.No. MDU CM31-Rajapalayam local, Virudhunagar district was used to investigate the genetic control of the growth, yield and quality traits are dominance or over dominance and in each the genotypes whether the traits are controlled by dominant or recessive alleles. All the six parents and their $30 \mathrm{~F}_{1}$ hybrids were raised in the field in Randomized Block Design with two replications. The various growth, yield and quality traits viz., vine length, number of primary branches, days to first male flower, days to first female flower, node to first male flower, node to first female flower, sex ratio, days to first harvest, number of fruits per vine, average fruit weight, fruit length, fruit diameter, yield per plant, flesh thickness, number of seeds per fruit, total soluble solids, beta carotene and dry matter content of fruits were recorded. The data were subject to Hayman's genetic analysis to investigate nature of expression and their alleles on the growth, yield and quality traits. The study showed that dominance alleles were present in $\mathrm{P}_{4}$ parent for vine length, sex ratio, number of fruits per plant, fruit yield per vine and beta carotene content. This parent also possessed recessive genes for traits such as, number of primary branches and days to first female flower. The parents $\mathrm{P}_{1}$ and $\mathrm{P}_{2}$ possessed recessive alleles for vine length, number of primary branches, number of fruits per plant and beta carotene and these parents also inherit dominant and recessive alleles for the traits, days to first female flower, sex ratio and fruit weight.

KEY WORDS : Pumpkin, Cucurbita moschata, Genetic analysis, Diallel graphical analysis

HOW TO CITE THIS ARTICLE : Krishnamoorthy, V. and Marxmathi, P. (2019). Diallel graphical analysis of growth, yield and quality traits in pumpkin (Cucurbita moschata Duch. ex. Poir). Asian J. Hort., 14(1) : 1-8, DOI : 10.15740/HAS/TAJH/14.1/1-8. Copyright@ 2019 : Hind Agri -Horticultural Society 